\title{
KEDUDUKAN HADIS DALAM JUZUK 2 KITAB KASYF AL-GHUMMAH FI AHWALIL MAUTA FIL BARZAKH WAL QIYAMAH
}

\author{
Muhammad Darul Ehsan Bin Derome dan Mohd Arif Nazri \\ Jabatan Pengajian al-Quran dan al-Sunnah \\ Fakulti Pengajian Islam, Universiti Kebangsaan Malaysia \\ darulehsan92@gmail.com dan mohdarif@ukm.edu.my
}

\begin{abstract}
:
This study examines the position of chapter 16 in the second volume of the Book of Kasyf al-Ghummah Fi Abwalil Mauta Fil Barzakh Wal Qiyamah by Syeikh Daud al-Fatani. The research shows that Sheikh Daud wrote this book to answer the demands of the people who wanted to know about death and doomsday. The characteristics of this book present a number of hadiths without specifying the position of the hadith. The findings of the 16 Hadiths find 3 Hadiths of Muttafaqun alaih, 7 are sahih, 1 is hasan, 2 hadiths are dhaif, 3 hadiths are not known to their original sources. Among the 13 hadiths found its source, 11 hadith are maqbul and 2 are mardud.

Keywords: Kedudukan Hadis, Kitab Kasyf al-Ghummah dan Syeikh Daud al-Fatani
\end{abstract}

\section{Pendahuluan}

Kajian kedudukan hadis di dalam Kitab Kasyf al-Ghummah karya Syeikh Daud al-Fatani amat penting dilakukan seperti juga kitab-kitab ilmu Islam yang lain. Hal ini telah menjadi tradisi, yang mana bukti inginkan yang terbaik serta menjaga kutelanan agama.

Makluman awal, kitab Kasyf al-Ghummah ini memfokuskan tentang kematian dan kiamat. Kitab ini dikenali sebagai karya akidah dan hadis. Karya ini telah memperlihatkan keunikan kerna karya hadis oleh Syeikh Daud amat terhad bilangannya.

Melalui artikel ini, kedudukan hadis akan memfokuskan terhadap hadishadis bab 16 di dalam juzuk 2 kitab Kasyf al-Ghummah berkaitan tentang Syurga dikelilingi dengan perkara yang tidak disukai manakala neraka dikelilingi dengan keinginan, serta sifat ahlinya. 
Bagi melengkapkan kajian ini, maklumat ringkas berhubung pengarang kitab dan pengenalan kitab di bahagian awal artikel. Selanjutnya fokus akan diberikan terhadap data-data kedudukan hadis yang didapati di dalam bab 16 juzuk 2 kitab Kasyf al-Ghummah.

\section{Biografi Pengarang}

Nama penuh Syeikh Daud Al-Fatani ialah Syeikh Wan Daud bin Syeikh Wan Abdullah bin Syeikh Wan Idris atau Wan Senik. Beliau juga dikenali sebagai 'Alim al-'Allamah al-'Arif al-Rabbani dan Sheikh Daud Keramat.' Ibunya bernama Wan Fathimah anak Wan Salamah bin Tok Banda wan Su bin Tok Kaya Rakna Diraja bin Andi Faqih Ali Datuk Maharajalela bin Mustafa Datu Jambu bin Sultan Muzaffar Waliuallah bin Sultan Abu Abdullah Umdatuddin. Bapa beliau pula bernama Wan Abdullah bin Wan Idris bin Tok Wan Abu Bakar bin Tok Kaya Pandak bin Andi Faqih Ali Datuk Maharajalela. $^{2}$

Beliau yang lebih dikenali sebagai Tok Syeikh Daud Patani ini mempunyai lima adik beradik iaitu Syeikh Wan Abdul Qadir, Syeikh Wan Abdul Rasyid, Syeikh Wan Idris dan seorang adik perempuan namanya Siti Khadijah. Beliau merupakan anak sulung di dalam keluarga dan merupakan yang paling Berjaya dan alim berbanding yang lain. ${ }^{3}$

Para pengkaji berselisih pendapat tentang tempat kelahirannya. Wan Mohd Saghir berpendapat bahawa beliau dilahirkan di Kampung Kerisek, Pattani. Abdullah al-Qari pula berpendapat bahawa beliau dilahirkan di Kmapung Bendang Gucil. ${ }^{4}$ Manakala Ismail Che Daud pula mengatakan bahawa beliau dilahirkan di Kampung Parit Marhum berhampiran dengan Kampung Kerisek, iaitu kira-kira 7 kilometer di sebelah selatan Bandar Patani sekarang. ${ }^{5}$

Tahun kelahirannya juga tidak dapat dipastikan kerana terdapat perselisihan pendapat dalam kalangan penyelidik mengenainya. Dalam catatancatatan beberapa keluarga penulis yang ada hubungan dengan beliau, ada yang

\footnotetext{
${ }^{1}$ Mohd Saleh Abdul Razak, Wasiat Sebelum Bergelar Ulama, (Kuala Lumpur : Telaga Biru, 2011), h xii.

2 Wan Mohd Saghir Abdullah, Syeikh Daud Bin Abdullah al-Fatani Ulama' dan Pengarang

Terulung Asia Tenggara, (Shah Alam: Penerbitan Hizbi, 1990), h 73.

${ }^{3}$ Taufan Prasetyo, Peranan Syeikh Daud Bin Abdullah Al-Fatani Dalam Memajukan Intelektual Islam Di Patani, (Jakarta : UIN Syarif Hidayatullah : 2015), h 30.

${ }^{4}$ Abdullah al-Qari, Pujangga Syeikh Daud al-Fatani, (dalam Majalah Dian : 1967), h 131.

${ }^{5}$ Ismail Che Daud, Tokoh-tokoh Ulama Semenanjung Melayu (1), (Kota Bharu : Majlis Ugama Islam dan Adat Istiadat Melayu Kelantan : 2001), h 19.
} 
mencatat tahun $1133 \mathrm{H}, 1153 \mathrm{H}$ dan tahun $1183 \mathrm{H}$. Ismail Che Daud menyatakan bahawa tarikh kelahirannya ialah pada $1183 \mathrm{H}$ bersamaan 1769M. ${ }^{6}$

Syeikh Daud al-Fatani meninggal dunia dan dimakamkan di Taif. Kuburnya bersampingan dengan kubur Saidina Abdullah bin Abbas iaitu sepupu Rasulullah SAW. Tahun kematiannya tidak diketahui dengan pasti. Walau bagaimanapun, ada yang berpendapat beliau meninggal dunia sekitar tahun $1847 \mathrm{M}$ dan ada juga yang menyebut tahun $1265 \mathrm{H}^{7}$

\section{Perkenalan Kitab Kasyf al-Ghummah}

Judul penuh karya ini ialah Kasyf al-Ghummah Fi Ahwal al-Mawta fi al-Barzakh wa al-Qiyamah. Selesai ditulis pada 20 Rabi'ul Awwal 1238H/1819M. Diberi nama sebagai Kasyf al-Ghummah kerana pada keseluruhannya menerangkan secara jelas tentang keadaan orang mati di adalam barzakh dan keadaan yang berlaku pada Hari Kiamat. Ia terdiri daripada 2 juzuk dan dicetak di bahagian tepi karya beliau yang paling besar iaitu Furu' al-Masail, namun ada juga yang dicetak berasingan.

Pada keseluruhan karya ini menceritakan tentang keadaan yang berkaitan dengan kematian, suasana di dalam kubur, keadaan di hari Akhirat, kisah syurga dan neraka. Kupasan kitab ini dibahagikan kepada dua juzuk. Juzuk pertama terdapat $14 \mathrm{Bab}$ manakala juzuk kedua terdapat 35 Bab. Tulisan ini untuk mengkaji kedudukan 16 buah hadis kesemuanya yang terdapat dalam bab 16 juzuk 2 Kitab Kasyf al-Ghummah Fi Ahwalil Mauta Fil Barzakh Wal Qiyamah karya Syeikh Daud al-Fatani.

Karya ini merupakan sebuah karya yang dipadankan dari karya Jalal alDin al-Suyuti iaitu Syarh al-Sudur dan karya Abd al-Wahab al-Sya'rani iaitu Mukhtasar Tadhkirah al-Qurtubi. Dalam erti kata lain karya ini memuatkan terjemahan hadith-hadith, athar dan pendapat para ulama terutama yang disebut oleh kedua-dua tokoh yang disebut diatas dalam dua karya tersebut. ${ }^{8}$

Banyak hadis-hadis yang menjadi sokongan kepada kenyataannya tanpa dinyatakan kedudukannya. Setelah itu, beliau menyebut hadis yang lain pula. Begitulah seterusnya sehingga berpindah kepada bab yang berikutnya. Walaupun begitu, Syeikh Daud al-Fatani tidak mempunyai bentuk yang selaras, ketika meriwayat hadis-hadis Rasulullah SAW. Beliau telah menggunakan

\footnotetext{
${ }^{6}$ Taufan Prasetyo, Peranan Syeikh Daud Bin Abdullah Al-Fatani Dalam Memajukan Intelektual Islam Di Patani, (Jakarta : UIN Syarif Hidayatullah : 2015), h 29.

${ }^{7}$ Wan Mohd Saghir:http://ulamanusantara.blogspot.com

${ }^{8}$ Rosni Wazir, Hadis-hadis Dalam Kasyf al-Ghummah Juzuk 1 ( Malaysia : Universiti Malaya : 2006), h 94.
} 
berbagai cara meriwayatkan hadis-hadis tersebut. Antara cara beliau meriwayatkan hadis:

1. Menyebut tokoh yang meriwayatkan hadis tersebut beserta maksud atau terjemahan hadis sahaja tanpa disertakan teks atau matan hadis, Contohnya: Riwayat al-Bukhari, "Bahawa Rasulullah bersabda, "neraka dikelilingi oleh semua jenis kehendak dan nafsu, manakala syurga dikelilingi oleh semua jenis perkara-perkara yang tidak diingini tidak suka."

2. Menyebut hadis terus dari Rasulullah SAW dan disertakan terjemahan hadis sahaja,

Contohnya: Dan pada Hadis Bahawa Rasulullah SAW bersabda "Nabi SAW bersabda: "Mahukah, aku khabarkan kepada kamu tentang penghuni surga Mereka terdiri daripada tiap-tiap orang yang merendah diri, dan jika dia mengambil Sumpah Allah bahawa dia akan melakukan perkara itu, maka Allah akan menunaikan janjinya (dengan? berbuat demikian). Mahukah aku khabarkan kepada kamu tentang orang-orang ahli neraka? Yaitu setiap orang yang kejam, ganas, bangga dan sombong."

3. Mengambil hadis terus dari sahabat yang meriwayatkan hadis tersebut

Contoh: 'Daripada Anas bin Malik RA katanya Rasulullah SAW bersabda...'

4. Menyebut perawi dan sahabat, kemudian diperturunkan terjemahannya.

Contoh: Dan Riwayat al-Bukhārī daripada Abū Hurairah, "Nabi berkata, "Syurga dan neraka (neraka) berhujah, dan Api (Neraka) itu berkata," Aku diberikan keistimewaan menerima sombong dan zalim. ' Syurga berkata, 'Apakah perkara itu dengan saya? Mengapa hanya yang lemah dan rendah diri terhadap manusia masuk saya?' Pada itu, maka Allah berfirman kepada syurga. Engkau adalah rahmat-Ku yang Aku berikan kepada sesiapa yang saya ingin hamba-hamba-Ku. Kemudian Allah berfirman kepada (neraka) Kebakaran Engkau adalah saya (cara) hukuman oleh yang saya menghukum sesiapa yang saya ingin hamba saya. Dan setiap kamu akan kenyang itu. ' Bagi Api (Neraka), ia tidak akan penuh sehingga Allah meletakkan kaki-Nya ke atas ia dimana ia akan berkata, 'Cukup! Cukup! ' Pada masa itu ia akan diisi, dan bahagian-bahagian yang berbeza akan datang lebih dekat antara satu sama lain; dan Allah tidak akan salah manamana makhluk-Nya. Berkenaan dengan Syurga, Allah akan mewujudkan makhluk yang baru untuk mengisi dengan."

5. Menyebut terjemahan sahaja 
Contohnya: Pada hadis 'Kamu syuhada Allah pada buminya, maka barangsiapa mensaksi kamu atasnya kejahatan wajib baginya neraka'.

6. Menyebut tokoh yang meriwayatkan hadis dan sahabat bersama teks hadis serta terjemahnnya

Contoh:

Riwayat Abū Dāwud dan al-Baihaqī daripada Abū Hurairah katanya :

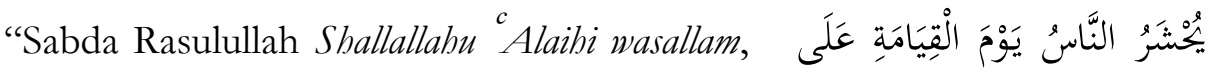

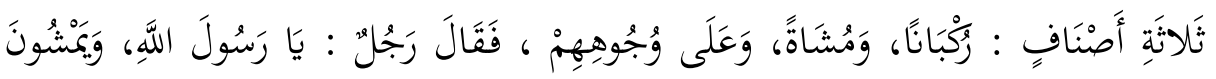

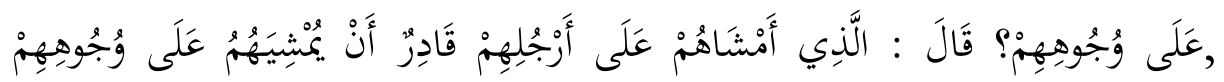
Artinya: berjalan manusia itu pada hari kiamat terbahagi kepada tiga golongan. Iaitu berkenderaan, berjalan kaki dan berjalan diatas muka mereka itu. Maka seorang lelaki bertanya : Ya Rasulullah, Adakah berjalan mereka itu di atas muka mereka? Sabdanya, yang menjalankan(kudrat Allah) mereka dengan kaki itulah yang menjalankan(kudrat Allah) mereka dengan muka mereka."

7. Menyebut tokoh yang meriwayat hadis dari Nabi beserta teks hadis tanpa terjemahan

Contoh: Riwayat Ibn Abi Syaibah marfu' sabda Nabi SAW

$$
\text { أكثر عذاب القبر من البول }
$$

8. Ada juga beliau menyebut hadis dari tokoh selepas sahabat

Contoh: 'Dari Asim anak Damrah daripada Saidina Ali RA katanya sabda Rasulullah SAW; makan olehmu dengan bithih.'

9. Menyebut matan atau teks hadis dan disertakan dengan terjemahannya sahaja tanpa menyebut perkara-perkara lain.

Contohnya:

$$
\text { إن الشيطان يأتى أحدكم قبل موته فيقول مت يهوديا مت نصرانيا }
$$

'Sesunggubnya syaitan akan datang kepada seseorang sebelum kematiannya, maka berkata ia mati olehmu Yabudi dan mati olehmu Nasrani.'

Bahkan karya ini merupakan sebuah karya Syeikh Daud al-Fatani yang unik dan menarik kerana ia menyentuh dua aspek utama dalam Islam iaitu akidah dan hadis. Walaupun kurang diberi perhatian oleh para sarjana akidah, kasyf al-Ghummah sudah mendapat perhatian apabila para sarjana mula menganggapnya sebagai salah sebuah karya hadis Syeikh Daud al-Fatani yang 
amat terhad bilangannya. Maka, ia boleh dianggap sebagai rujukan yang baik jika ingin melihat hadis-hadis yang berkaitan.

Kesimpulannya, karya ini mempunyai hadis-hadis yang sangat banyak dan didatangkan dalam pelbagai keadaan. Syeikh Daud al-Fatani hanya mengulas sebahagian kecil sahaja hadis yang termuat dalam kitabnya itu. Oleh itu, kajian ini menjadi satu kewajipan untuk diperjelaskan kedudukan dan martabat hadis-hadis tersebut yang mana pengkaji hanya menukilkan penilaian hadis yang telah dilakukan oleh para ulama yang telah mengtakhrij hadis tersebut sebagai dapatan kajian.

\section{Kedudukan Hadis Bab 16}

\section{a) Hadis Maqbul}

\section{HADIS 1}

Riwayat al-Bukhari,

"Bahawa Rasulullah bersabda, "neraka dikelilingi oleh semua jenis kehendak dan nafsu, manakala syurga dikelilingi oleh semua jenis perkara-perkara yang tidak diingini tidak suka." 10

Matan Hadis

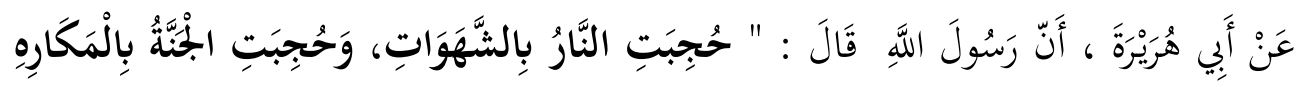

Takhrij: Hadis ini diriwayatkan oleh Imam al-Bukhari, Imam Muslim dan Imam al-Tirmizi.

1. Sahih al-Bukhari, Hadis nombor 6487, Kitab al-Riqaiq, Bab Hujibat alNar Bi al-Syabwat, Juzuk $4 .^{12}$

2. Sahih Muslim,Hadis 2822, Kitab al-Jannah Wa Sifat Ni'amiba Wa 'Abliba, Juzuk. $4 .^{13}$

\footnotetext{
${ }^{9}$ Fauzi Deraman, Kedudukan Hadis Dalam Kitab Jawi : Karya syakh Daud al-Fatani, (Malaysia : Universiti Malaya : 1997) h 431

${ }_{10}$ Daud al-Fatani, Kasyf al-Ghummah Fi Ahwal al-Mawta fi al-Barzakh wa al-Qiyamah, (Kuala Lumpur : Khazanah al-Fathaniyah : 2009M), h 216.

${ }^{11}$ Al-Bukhari, Abu 'Abd Allah Muhammad bin Ismail, Shahih al-Bukhari (Qaherah : al-Tab ${ }^{\mathrm{c}}$ ah al-Salafiah : 1400H), h 189 j 4 .

${ }^{12} \mathrm{Al}-\mathrm{Bukhari}, \mathrm{Abu}$ 'Abd Allah Muhammad bin Ismail, Shahih al-Bukhari, (Qaherah : al-Tab ${ }^{\mathrm{c}}$ ah al-Salafiah : 1400H), h 189 j 4 .

${ }^{13}$ Muslim, Muslim Ibn al-Hajāj Abū al-Hasan al-Qushairi al-Naysābūri, Ṣaḥị̣ Muslim, (Beyrūt : Dār Ihyā̄' al-Turāth al-cArabi : 1412H), h 2174 j4.
} 
3. Jami'

al-Tirmizi,

Hadis

nombor

2559 ,

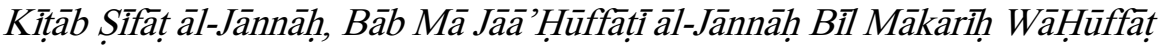
īàl-Nār Bī āl-Syāḥwāt..$^{14}$

Ulasan

Hadis ini dinukil oleh Syeikh Daud secara mafhum sahaja dengan menyatakan bahawa ianya Riwayat al-Bukhari sebagai hadis utama bagi bab ini. Berdasarkan mafhum yang diberi, penulis telah menemukan matan seperti diatasyang mana merupakan daripada Imam al-Bukhari. Kedudukan hadis ini mencapai taraf Mutafaqun 'alaih oleh Imam al-Nawawi di dalam Riyadush Shalihin. ${ }^{15}$ Maka tiada keraguan baginya.

\section{HADIS 2}

Pada satu riwayat bagi Imam al-Tirmizi

"Bahawa Rasulullah SAW bersabda :Apabila Allah menjadikan syurga dan neraka, Dia menghantar Jibril ke syurga, berkata:". Lihatlah ia dan apa yang saya sediakan di dalamnya untuk penghuninya "Beliau (saw) berkata:" Maka datanglah ia kepadanya dan melihat ia, dan pada apa yang telah Allah sediakan di dalamnya dia (Jibril) berkata: Sesungguhnya, dengan Kuasa anda, tidak ada yang mendengar melainkan bahawa dia akan memasukinya' . Kemudian Dia memberi perintah untuk itu akan dikelilingi dengan kesusahan Beliau berkata: Pulanglah kepadanya dan melihat ia, dan apa yang saya sediakan di dalamnya untuk penghuninya. "Beliau (saw) berkata:" Maka beliau kembali ke ia dan mendapati ia dikelilingi dengan kesusahan Beliau kembali kepada-Nya dan berkata: Sesungguhnya, dengan Kuasa anda, saya takut bahawa tidak akan memasukinya' Dia (s.a.w) berkata: 'Pergi ke neraka dan melihat ia dan apa yang saya sediakan di dalamnya untuk penghuninya.' Jadi dia mendapatinya, satu bahagian daripadanya menunggang yang lain supaya dia kembali kepada-Nya dan berkata:. '. Sesungguhnya, dengan Kuasa anda, tidak ada yang mendengar dan kemudian memasukinya' Maka Dia memberi perintah untuk itu akan dikelilingi dengan keinginan, lalu berfirman: '. Kembalilah kepadanya,' Maka dia (Jibril) kembali kepadanya, maka dia berkata: "Sesungguhnya, dengan

\footnotetext{
14 Al-Tirmīdhī, Muhammad bin Isa Ibn Sawrah ibn Mūsā, Sunan al-Tirmīdhī, (Riyāẹ : Maktabat al-Ma arif : t.th) h 577.

15 https://sunnah.com/riyadussaliheen/1/101
} 
Kebesaran-Mu, aku takut bahawa tidak akan disimpan daripadanya kecuali bahawa dia akan memasukinya."16

Matan Hadis :

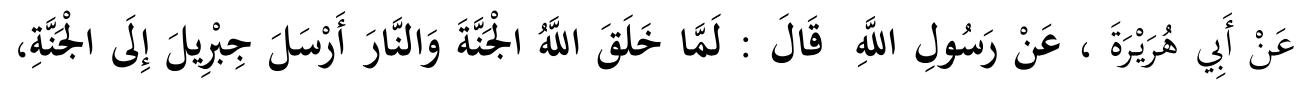

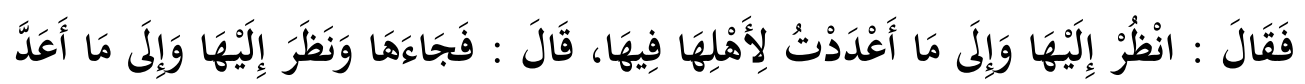

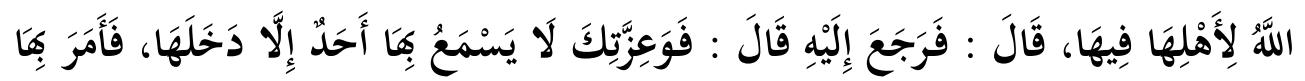

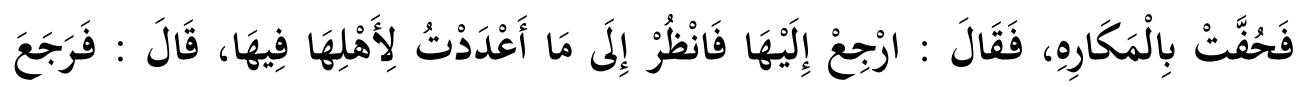

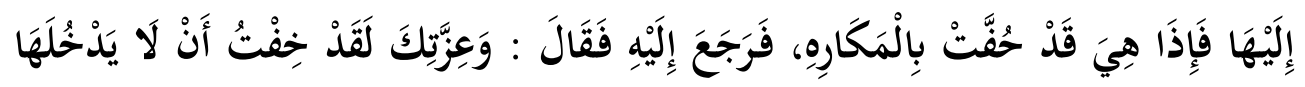

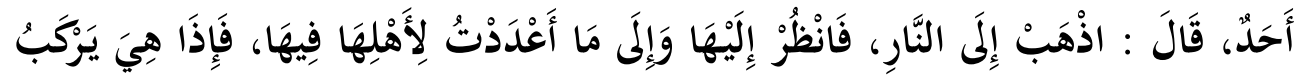

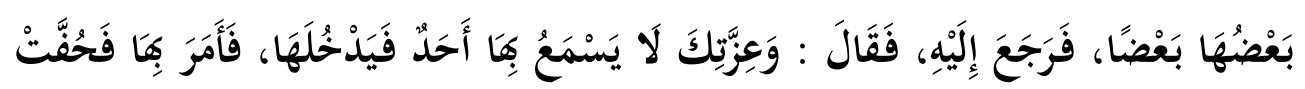

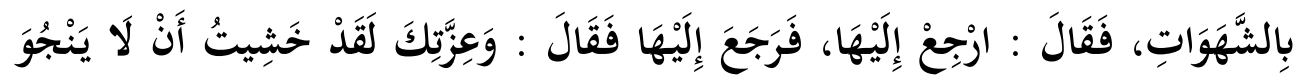

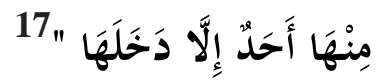
Takhrij : Hadis ini diriwayatkan oleh Imam al-Tirmizi, Imam Abu Dawud dan Imam Al-Nasa'i.

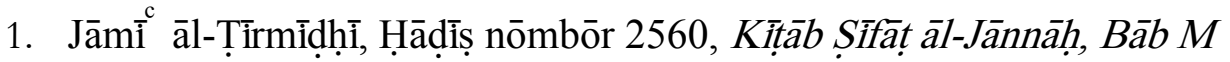

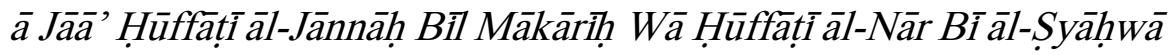
$t^{18}$

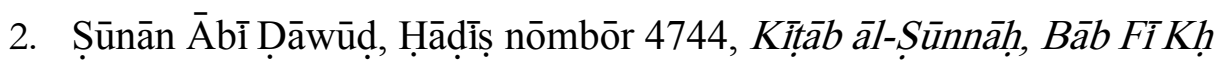
àlqū àl-Jānnāḥ Wāa àl-Nār. ${ }^{19}$

\footnotetext{
${ }^{16}$ Daud al-Fatani, Kasyf al-Ghummah Fi Ahwal al-Mawta fi al-Barzakh wa al-Qiyamah, (Kuala Lumpur : Khazanah al-Fathaniyah : 2009M), h 216.
} 17

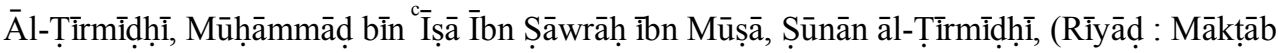
àt āl-Māēàif : t.ṭ̣) h 577.

18

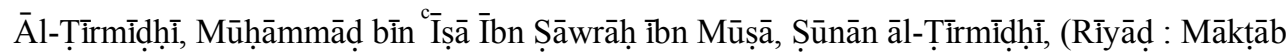
àt àl-Mā̄ārīf : t.ṭ̣) h 577. 


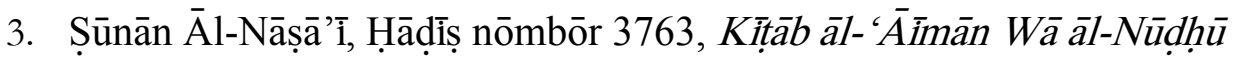 r, Bāb āl-Hālfü Bī İ́zzătịilāạ. ${ }^{20}$}

Ulasan

Hadis yang kedua di dalam bab ini, Syeikh Daud telah mendatangkan hadis riwayat Imam Tirmidhī seperti yang dinyatakan di atas. Penulis telah menemukan beberapa hadis yang mana turut diriwayat oleh Imam Abū Dāwūd dan Imam Al-Nasā'i. Hadis ini telah dihukumkan Hasan Șạ̣ị̣ oleh Imam Tirmīdhī, Imam Abū Dāwūd, Imam al-Nasā'i dan Syeikh al-Albānī mengatakan Ḥasan. Jika berdasarkan kedudukan hadis yang dinyatakan ianya tingkatan yang kedua tertinggi selepas Șahịh. Maka tiada keraguan pada hadis yang kedua ini.

\section{HADIS 3}

Dan Riwayat al-Bukhārī daripada Abū Hurairah, "Nabi berkata, "Syurga dan neraka (neraka) berhujah, dan Api (Neraka) itu berkata," Aku diberikan keistimewaan menerima sombong dan zalim. ' Syurga berkata, 'Apakah perkara itu dengan saya? Mengapa hanya yang lemah dan rendah diri terhadap manusia masuk saya? ' Pada itu, maka Allah berfirman kepada syurga. Engkau adalah rahmat-Ku yang Aku berikan kepada sesiapa yang saya ingin hamba-hamba-Ku. Kemudian Allah berfirman kepada (neraka) Kebakaran Engkau adalah saya (cara) hukuman oleh yang saya menghukum sesiapa yang saya ingin hamba saya. Dan setiap kamu akan kenyang itu. ' Bagi Api (Neraka), ia tidak akan penuh sehingga Allah meletakkan kaki-Nya ke atas ia dimana ia akan berkata, 'Cukup! Cukup! ' Pada masa itu ia akan diisi, dan bahagian-bahagian yang berbeza akan datang lebih dekat antara satu sama lain;

19

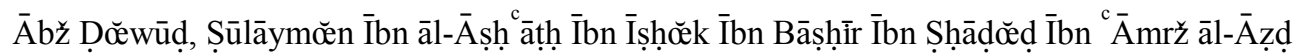

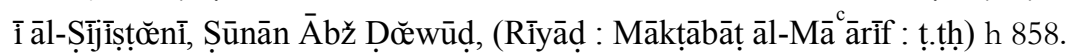
20

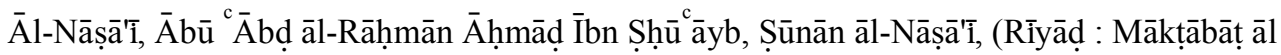
-Mā àrīf : ț.ṭ̣) h 582. 
dan Allah tidak akan salah mana-mana makhluk-Nya. Berkenaan dengan Syurga, Allah akan mewujudkan makhluk yang baru untuk mengisi dengan." 21 Matan Hadis

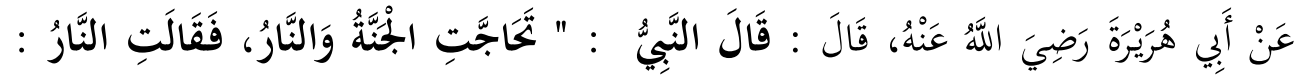

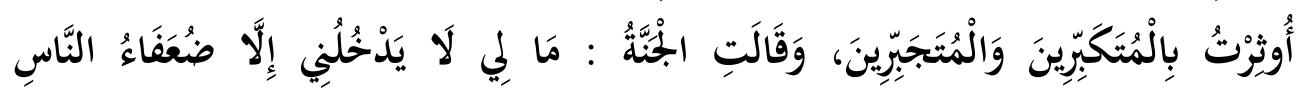

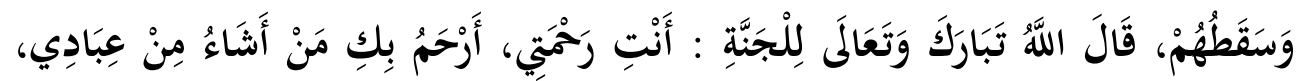

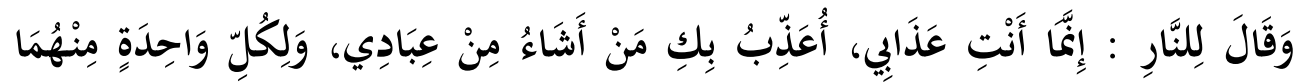

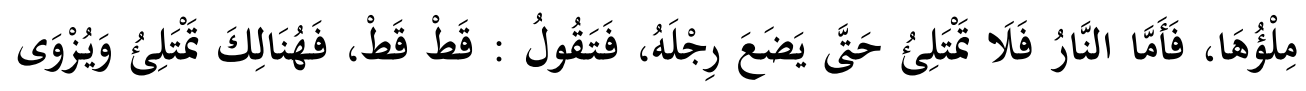

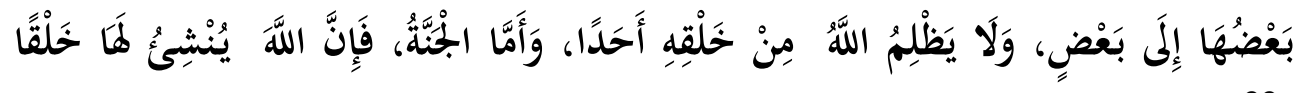
$22 "$

Takhrij : Hadis ini diriwayatkan oleh Imam al-Bukhārī, Imam Muslim dan Imam al-Tirmidhī.

1. Șāḥịh āl-Būkhārī, Ḥāḍịs nōmbōr 4850, Kịtāb Ṭātșīr āl-Qūr ān, Bāb Q

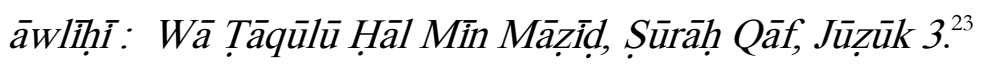

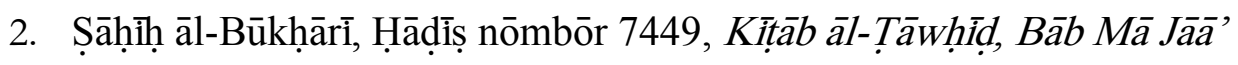

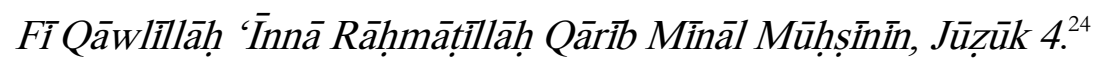

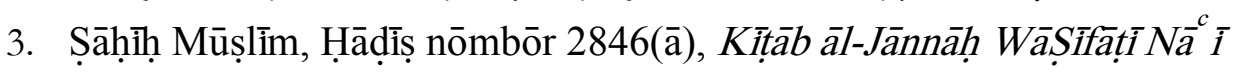
mịhā Wā Āhlị̣ā, Jüzūk $4^{25}$.

\footnotetext{
${ }^{21}$ Daud al-Fatani, Kasyf al-Ghummah Fi Ahwal al-Mawta fi al-Barzakh wa al-Qiyamah, (Kuala Lumpur : Khazanah al-Fathaniyah : 2009M), h 217.

${ }^{22}$ Al-Bukhārī, Abū Abd Allah Muhammad bin Ismail, Șaḥị al-Bukhārī, (Qaherah : al-Ṭab ah al-Salafiah : 1400H), h $296 \mathrm{j} 3$.

${ }^{23}$ Al-Bukhārī, Abū ${ }^{\mathrm{c}}$ Abd Allah Muhammad bin Ismail, Șaḥị al-Bukhārī, (Qaherah : al-Ṭab ah al-Salafiah : 1400H), h $296 \mathrm{j} 3$.

${ }^{24}$ Al-Bukhārī, Abū ${ }^{\mathrm{c}}$ Abd Allah Muhammad bin Ismail, Șaḥị al-Bukhārī, (Qaherah : al-Ṭab ah al-Salafiah : 1400H), h 394 j 4 .

${ }^{25}$ Muslim, Muslim Ibn al-Hajāj Abū al-Hasan al-Qushairi al-Naysābūri, Ṣaḥị̣ Muslim, (Beyrūt : Dār Ihyā̄' al-Turāth al-cArabi : 1412H), h 2846 j4.
} 


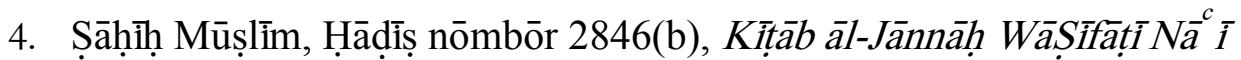
mịhà Wā Āhlị̂āa, Jūzūk $4{ }^{26}$

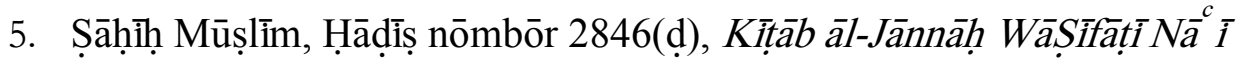
mịhà Wā Āhlị̣ā, Jūzūk $4{ }^{27}$

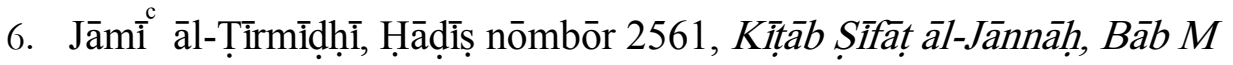

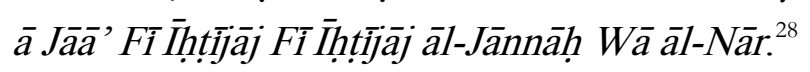

Ulasan

Hadis ketiga ini didatangkan Syeikh Daud secara mafhum sahaja. Beliau menyatakan bahawa ianya diriwayatkan oleh Imam al-Bukhārī. Berdasarkan mafhum, penulis telah menemukan hadis seperti yang dinyatakan di atas dan turut diriwayat oleh Imam Muslim dan Imam al-Tirmīdhī. Kedudukan hadis yang ketiga ini adalah Sahih. Maka tiada keraguan padanya.

\section{HADIS 4}

Riwayat Muslim daripada ${ }^{\mathrm{c}}$ Iyad bin Himar bahawa Rasulullah bersabda pada satu hari di dalam khutbah.

"Ahli Syurga tiga: Orang yang memegang kuasa dan hanya adil, orang yang benar dan telah dikurniakan dengan kuasa untuk melakukan perbuatanperbuatan yang baik. Dan orang yang pengasih dan baik hati terhadap saudarasaudaranya dan kepada setiap muslim yang soleh, dan orang yang tidak menghulurkan tangannya walaupun mempunyai keluarga yang besar untuk menyokong. Dan Dia berkata: penghuni Neraka itu adalah lima: yang lemah yang tidak mempunyai kuasa untuk (menjauhi kejahatan), yang (riang) yang mengejar (segala-galanya tanpa mengira hakikat bahawa ia adalah baik atau jahat) dan yang tidak mempunyai apa-apa penjagaan untuk mereka keluarga atau untuk kekayaan mereka. Dan orang-orang yang tidak jujur yang tamak tidak boleh disembunyikan walaupun dalam hal perkara-perkara kecil. Dan yang ketiga. yang mengkhianati anda. pagi dan petang, berkenaan dengan

${ }^{26}$ Muslim, Muslim Ibn al-Hajāj Abū al-Hasan al-Qushairi al-Naysābūri, Șahịḥ Muslim, (Beyrūt : Dār Ihyā' al-Turāth al-cArabi : 1412H), h 2846 j4.

${ }^{27}$ Muslim, Muslim Ibn al-Hajāj Abū al-Hasan al-Qushairi al-Naysābūri, Ṣaḥị̣ Muslim, (Beyrūt : Dār Ihyā' al-Turāth al-cArabi : 1412H), h 2846 j4.

28 Al-Tirmīinhī, Muhammad bin Isa Ibn Sawrah ibn Mūsā, Sunan al-Tirmīinhī, (Riyāḍ :

Maktabat al-Ma ${ }^{\square}$ arif : t.th) h 577. 
keluarga anda dan harta anda. Beliau juga memberitahu perkara yang bakhil dan pendusta dan orang-orang yang berada dalam tabiat mendera rakyat dan menggunakan bahasa lucah dan busuk. Abu Ghassan dalam riwayatnya tidak membuat penyebutan "Belanja dan ada akan dibelanjakan untuk anda."29

Matan Hadis

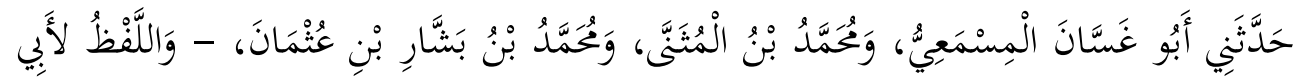

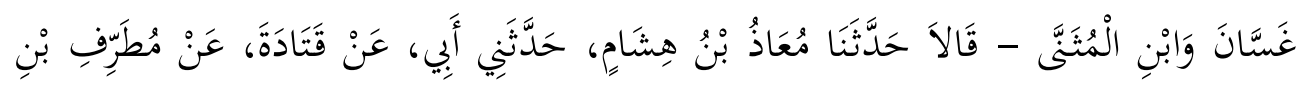

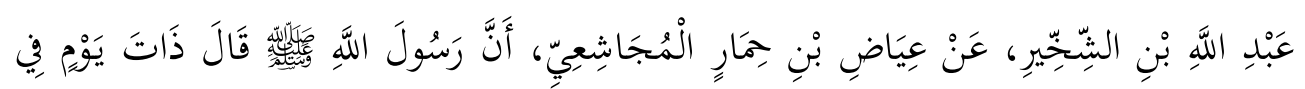

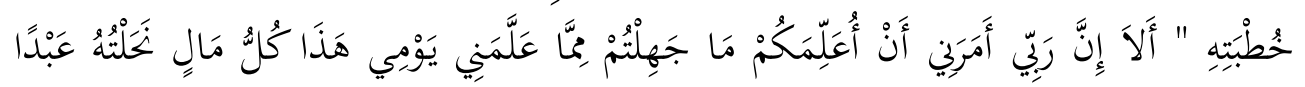

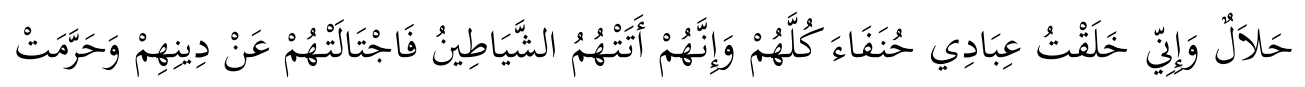

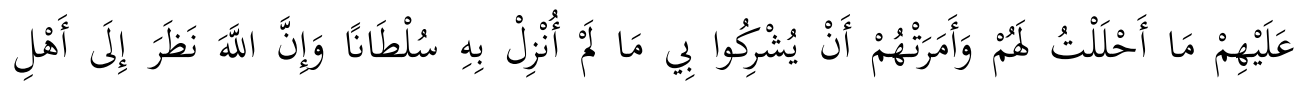

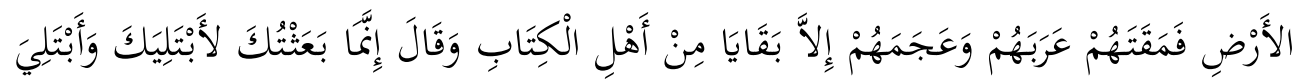

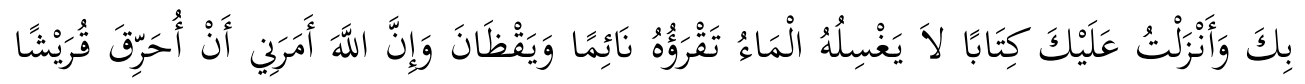

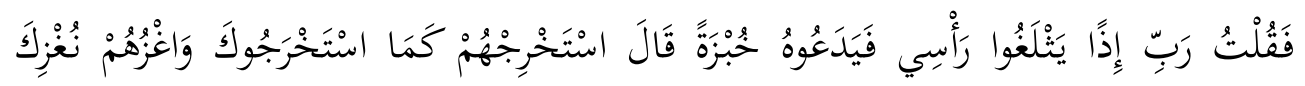

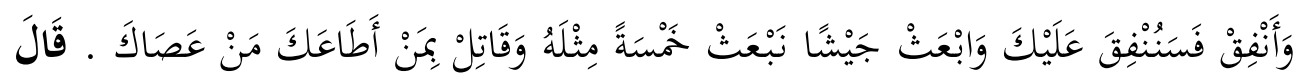

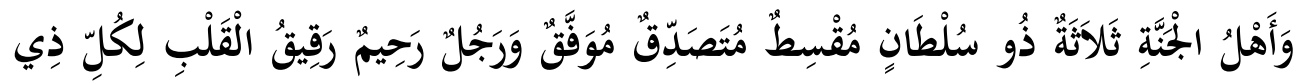

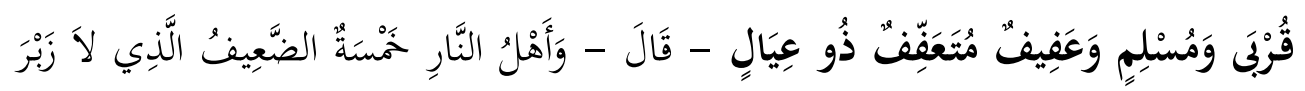

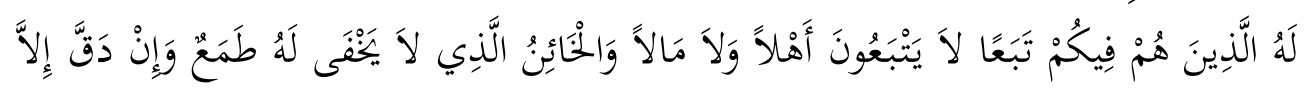

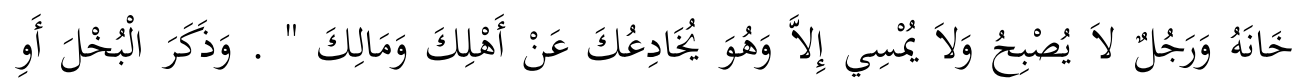

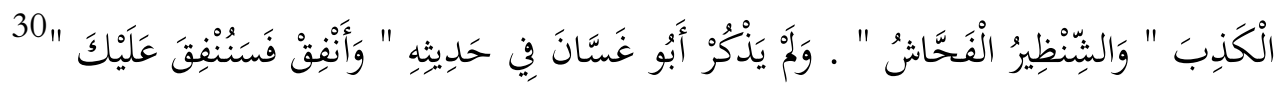

Takhrij Hadis : Hadis ini diriwayatkan oleh Imam Muslim

\footnotetext{
${ }^{29}$ Daud al-Fatani, Kasyf al-Ghummah Fi Ahwal al-Mawta fi al-Barzakh wa al-Qiyamah, (Kuala Lumpur : Khazanah al-Fathaniyah : 2009M), h 217.

${ }^{30}$ Muslim, Muslim Ibn al-Hajāj Abū al-Hasan al-Qushairi al-Naysābūri, Ṣaḥị̣ Muslim, (Beyrūt

: Dār Ihyā̄' al-Turāth al-cArabi : 1412H), h 2917 j4.
} 


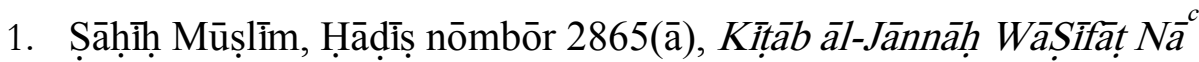

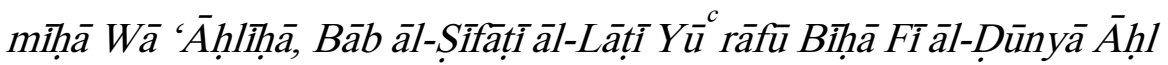
ū àl-Jānnāḥ Wā Āḥlū āl-Nār, Jūzūuk 4. ${ }^{31}$

Ulasan

Hadis keempat ini merupakan sebuah hadis yang panjang, namun Syeikh Daud hanya mendatangkan sebahagian sahaja secara mafhum. Berdasarkan mafhum, penulis menemukan matan yang dinyatakan diatas. Hadis ini diriwayat oleh Imam Muslim sahaja dan tidak didapati di dalam 5 kitab utama hadis lain. Kedudukan hadis ini adalah Șahịh. Maka tiada keraguan padanya.

\section{HADIS 5}

Dan pada Hadis Bahawa Rasulullah SAW bersabda

"Nabi SAW bersabda: "Mahukah, aku khabarkan kepada kamu tentang penghuni surga Mereka terdiri daripada tiap-tiap orang yang merendah diri, dan jika dia mengambil Sumpah Allah bahawa dia akan melakukan perkara itu, maka Allah akan menunaikan janjinya (dengan? berbuat demikian). Mahukah aku khabarkan kepada kamu tentang orang-orang ahli neraka? Yaitu setiap orang yang kejam, ganas, bangga dan sombong." 32

Matan Hadis

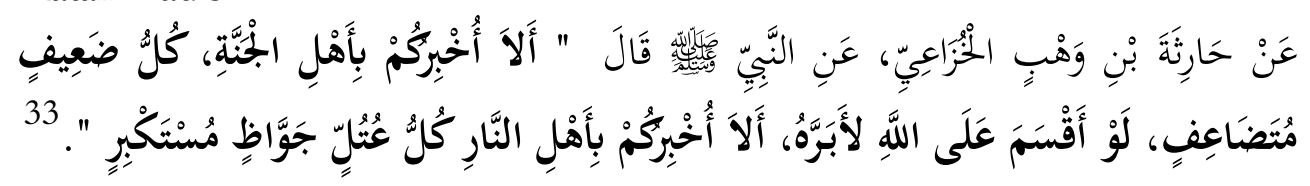

Takhrij: Hadis ini diriwayatkan oleh Imam al-Bukhārī, Imam Muslim, Imam alTirmidhỉ dan Imam Ibn Mājah.

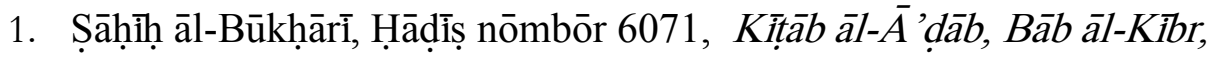
Jūzūk $4 .^{34}$

Muslim, Muslim Ibn al-Hajāj Abū al-Hasan al-Qushairi al-Naysābūri, Șaḥị̣ Muslim, (Beyrūt : Dār Ihyā’ al-Turāth al-cArabi : 1412H), h 2917 j4.

${ }^{32}$ Daud al-Fatani, Kasyf al-Ghummah Fi Ahwal al-Mawta fi al-Barzakh wa al-Qiyamah, (Kuala Lumpur : Khazanah al-Fathaniyah : 2009M), h 218.

${ }^{33}$ Al-Bukhārī, Abū ${ }^{\mathrm{c}}$ Abd Allah Muhammad bin Ismail, Șaḥị̣ al-Bukhārī, (Qaherah : al-Ṭab ${ }^{\square}$ ah al-Salafiah : 1400H), h 104 j 4 . 


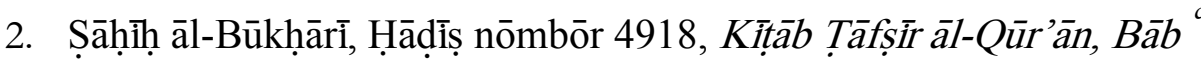

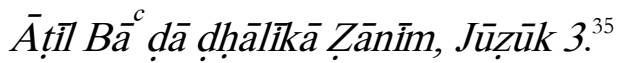

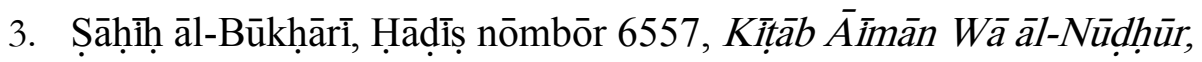

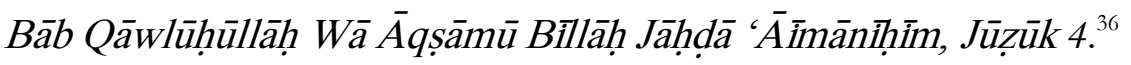

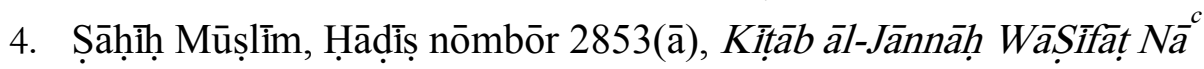
mị̣ā Wā 'Āḥlị̣ā, Bāb āl-Nār Yāọkḥūlūḥā āl-Jābbārūn Wā āl-Jānnāḥ Yāọkhūlūhāa àl-Dḥūā fā', Jūzūūk 4. ${ }^{37}$

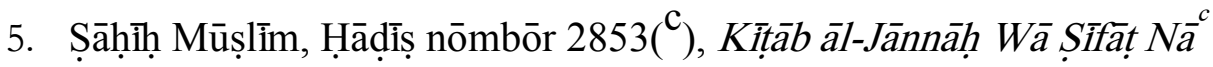
mị̂ā Wā 'Āḥlị̣ā, Bāb āl-Nār Yāọkḥūlūḥā āl-Jābbārūn Wāāl-Jānnāḥ

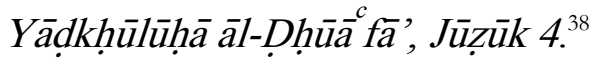

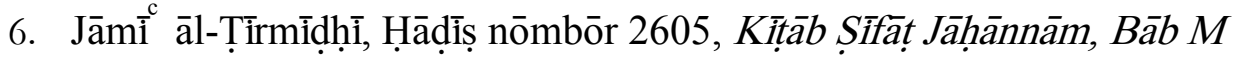

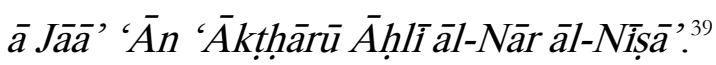

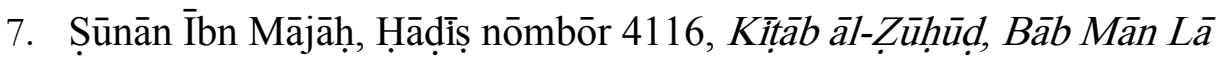
Yūā'bịhì Lāḥü..$^{40}$

Ulasan

Hadis kelima ini dinukilkan oleh Syeikh Daud secara mafhum dengan menyatakan bahawa pada hadis Rasulullah SAW bersabda. Beliau telah memulakan penulisan dengan menyatakan seperti diatas kemudian

\footnotetext{
34 Al-Bukhārī, Abū Abd Allah Muhammad bin Ismail, Șaḥịh al-Bukhārīi, (Qaherah : al-Ṭab ${ }^{\square}$ ah al-Salafiah : 1400H), h 104 j 4 .

${ }^{35}$ Al-Bukhārī, Abū ${ }^{\mathrm{c}} \mathrm{Abd}$ Allah Muhammad bin Ismail, Șaḥịh al-Bukhārī, (Qaherah : al-Ṭab ${ }^{\square}$ ah al-Salafiah : 1400H), h 315 j 3 .

${ }^{36}$ Al-Bukhārī, Abū Abd Allah Muhammad bin Ismail, Șaḥị̣ al-Bukhārī, (Qaherah : al-Ṭab ah al-Salafiah : $1400 \mathrm{H})$, h $220 \mathrm{j} 4$.

${ }^{37}$ Muslim, Muslim Ibn al-Hajāj Abū al-Hasan al-Qushairi al-Naysābūri, Ṣaḥị̣ Muslim, (Beyrūt : Dār Ihyā' al-Turāth al-cArabi : 1412H), h 2190 j4.

${ }^{38}$ Muslim, Muslim Ibn al-Hajāj Abū al-Hasan al-Qushairi al-Naysābūri, Șaḥị̣ Muslim, (Beyrūt : Dār Ihyā̄al-Turāth al-cArabi : 1412H), h 2190 j4.

${ }^{39}$ Al-Tirmīdhī, Muhammad bin Isa Ibn Sawrah ibn Mūsā, Sunan al-Tirmīdhī, (Riyāẹ :

Maktabat al-Ma $\square$ arif : t.th) h 586 .

${ }^{40}$ Ibn Mājah, Abū cAbd Allah Muhammad Ibn Yazid al-Qazwini,Sunan Ibn Mājah, (, (Riyạ̣̄ : Maktabat al-Ma arif : t.th) h 685.
} 
mendatangkan hadis. Penulis mendapati bahawa ianya diriwayatkan oleh Imam al-Bukhārī, Muslim, al-Tirmīdhī dan Ibn Mājah. Kedudukan hadis ini adalah Șahịḥ.

\section{HADIS 6}

Pada satu riwayat : 'Ahli neraka itu orang yang dicerca'.

Matan Hadis

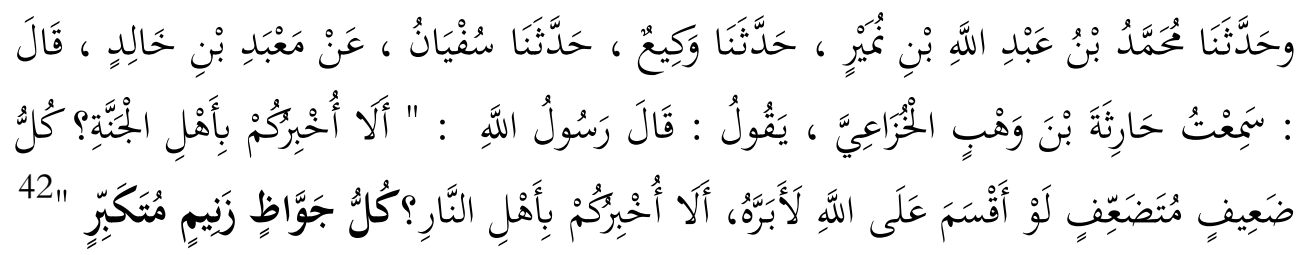

Takhrij: Hadis ini diriwayatkan oleh Imam Muslim.

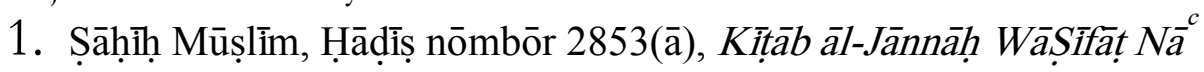
mịhā Wā 'Āḥlị̣ā, Bāb āl-Nār Yāọkhūūūḥā āl-Jābbārūn Wā āl-Jānnāḥ Yāọkhūūūhā āl-Ḍhūāa fã', Jūzūk $4{ }^{43}$

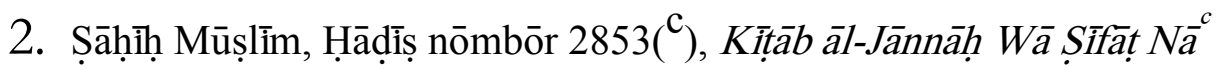
mịnā Wā 'Āḥlị̣ā, Bāb āl-Nār Yāọkhūūūḥā āl-Jābbārūn Wā āl-Jānnāḥ Yāọkhūlūhāa āl-Ḍhūāa fã', Jūzūk $4^{44}$

Ulasan

Syeikh Daud memberi secara mafhum dan sangat ringkas. Beliau hanya menyatakan pada satu riwayat, ahli neraka itu orang yang dicerca. Maka berdasarkan itu, penulis mendapati hadis keenam ini hanya diriwayatkan oleh Imam Muslim. Kedudukannya adalah Șaḥị̣.

\footnotetext{
${ }^{41}$ Daud al-Fatani, Kasyf al-Ghummah Fi Ahwal al-Mawta fi al-Barzakh wa al-Qiyamah, (Kuala Lumpur : Khazanah al-Fathaniyah : 2009M), h 218.

${ }^{42}$ Muslim, Muslim Ibn al-Hajāj Abū al-Hasan al-Qushairi al-Naysābūri, Șaḥị̣ Muslim, (Beyrūt : Dār Ihyā' al-Turāth al-cArabi : 1412H), h 2190 j4.

${ }^{43}$ Muslim, Muslim Ibn al-Hajāj Abū al-Hasan al-Qushairi al-Naysābūri, Șaḥị̣ Muslim, (Beyrūt : Dār Ihyā' al-Turāth al-cArabi : 1412H), h 2190 j4.

${ }^{44}$ Muslim, Muslim Ibn al-Hajāj Abū al-Hasan al-Qushairi al-Naysābūri, Șaḥị̣ Muslim, (Beyrūt : Dār Ihyā̄' al-Turāth al-cArabi : 1412H), h 2190 j4.
} 


\section{HADIS 7}

Pada hadis

'Kamu syuhada Allah pada buminya, maka barangsiapa mensaksi kamu atasnya kejahatan wajib baginya neraka'. ${ }^{45}$

Matan Hadis

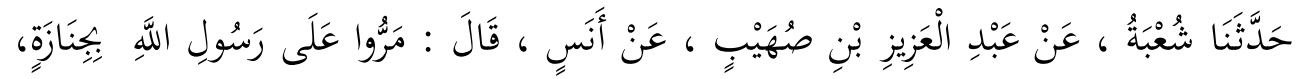

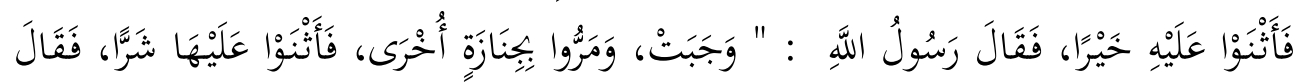

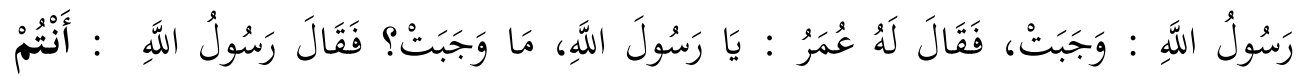

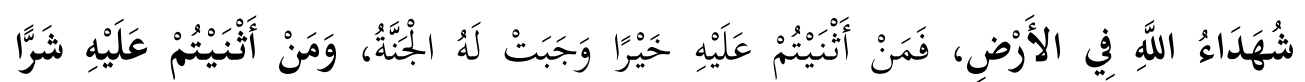

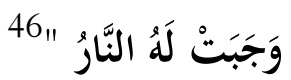

Takhrij : Hadis ini diriwayatkan oleh Abī Dāwud.

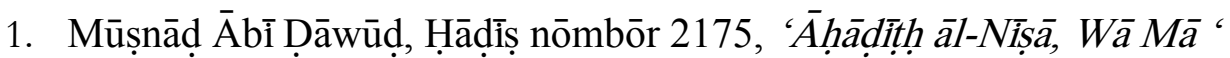

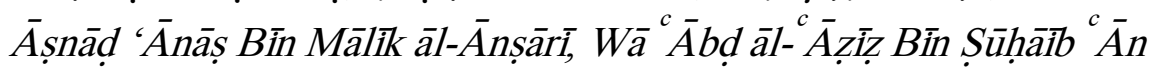
'Ānāṣ, Jūzūk 3. ${ }^{47}$

Ulasan

Hadis ini dinukilkan secara mafhum oleh Syeikh Daud al-Fatani. Maka penulis telah menemukan matan hadis yangsama dengan mafhum, ianya diriwayatkan oleh Abu Dāwūd al-Ṭiyālūsī. Bahkan hadis ini turut diriwayatkan oleh Imam al-Bukhārī, Muslim, Tirmīdhī, al-Nasā'i dan Ibn Mājah dengan sedikit berbeza dari segi lafaz. ${ }^{48}$ Kedudukan Hadis ini adalah Șahịh. Maka tiada keraguan padanya.

\footnotetext{
${ }^{45}$ Daud al-Fatani, Kasyf al-Ghummah Fi Ahwal al-Mawta fi al-Barzakh wa al-Qiyamah, (Kuala Lumpur : Khazanah al-Fathaniyah : 2009M), h 218.

${ }^{46}$ Sulaiman bin Dāwūd bin al-Jārūd, Musnad Abī Dāwūd al-Ṭiyālusī, JJạirah, Maktabah Hajar : 1999M), h 541.

${ }^{47}$ Sulaiman bin Dāwūd bin al-Jārūd, Musnad Abī Dāwūd al-Ṭiyālusī, Jazirirah, Maktabah Hajar : 1999M), h 541.

${ }^{48}$ Sulaiman bin Dāwūd bin al-Jārūd, Musnad Abī Dāwūd al-Ṭiyālusī, Jazirirah, Maktabah Hajar : 1999M), h 541 .
} 


\section{HADIS 11}

Riwayat Syaikhani

'Nabi SAW bersabda: "Jika Allah mencintai seseorang, Dia memanggil Jibril berkata:". Allah menyukai fulan; Wahai Jibril, suka dia ' Maka Jibril pun akan mengasihi dia dan kemudian Jibril akan membuat pengumuman di kalangan penduduk langit, 'Allah suka dia dan dia, oleh itu, anda perlu suka dia juga.' Jadi, seluruh penduduk langit akan mengasihi dia dan kemudian ia diberikan diperkenankan oleh bangsa di bumi. ${ }^{49}$

Matan Hadis

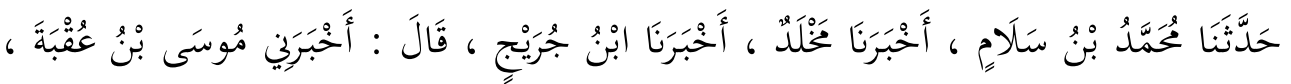

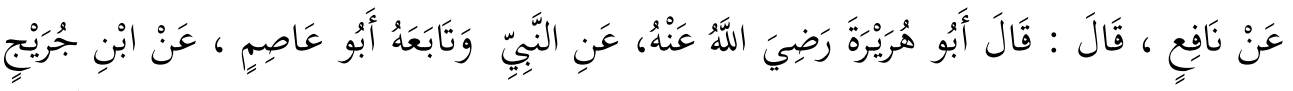

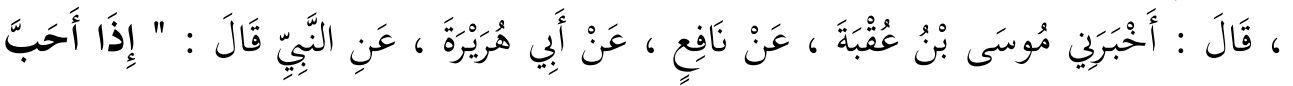

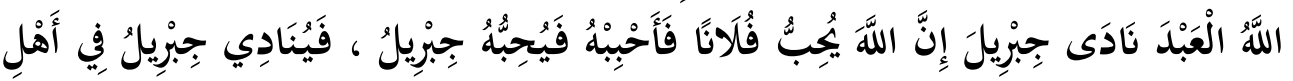

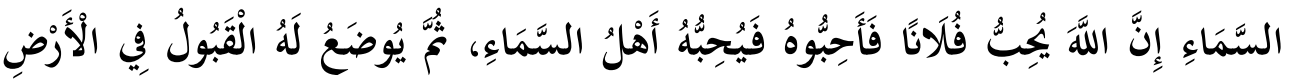
50 "

Takhrij: Hadis ini diriwayatkan oleh Imam al-Bukhārī, Muslim dan al-Tirmidhī.

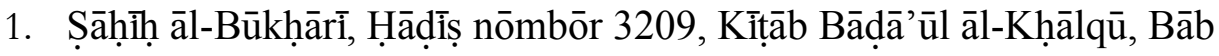
Ḍ̣ikrū āl-Mālā' ’̉kāh, Jūẓūk 2. ${ }^{51}$

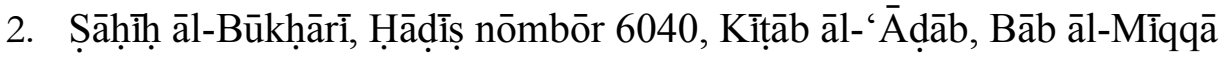
ḥ Mīnāllāḥ, Jūẓūk $4 .^{52}$

\footnotetext{
${ }^{49}$ Daud al-Fatani, Kasyf al-Ghummah Fi Ahwal al-Mawta fi al-Barzakh wa al-Qiyamah, (Kuala Lumpur : Khazanah al-Fathaniyah : 2009M), h 218.

${ }^{50}$ Al-Bukhārī, Abū Abd Allah Muhammad bin Ismail, Ṣaḥị̣ al-Bukhārī, (Qaherah : al-Ṭab ah al-Salafiah : 1400H), h 424 j 2 .

${ }^{51}$ Al-Bukhārī, Abü ${ }^{\mathrm{c}}$ Abd Allah Muhammad bin Ismail, Ṣaḥị̣ al-Bukhārī, (Qaherah : al-Ṭab ah al-Salafiah : 1400H), h 424 j 2 .

${ }^{52}$ Al-Bukhārì, Abü Abd Allah Muhammad bin Ismail, Șaḥị̣ al-Bukhārī, (Qaherah : al-Ṭab ah al-Salafiah : 1400H), h 98 j 4 .
} 


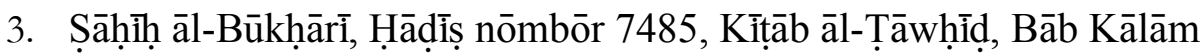
àl-Rāb Mā̄ ā Jỉbrîl Wā Nị̣̂āullāḥ āl-Mālā'ỉkāḥ, Jūzūk $4{ }^{53}$

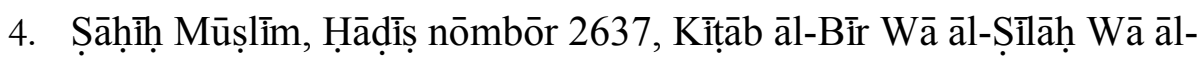

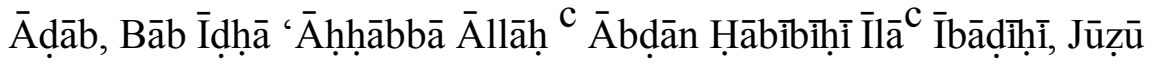
$\mathrm{k} 4 .^{54}$

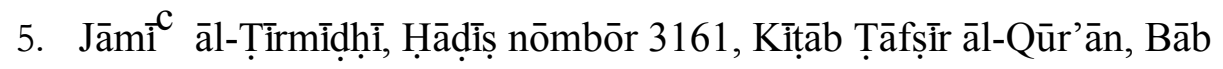
Wā Mīn Ṣūrāh Māryām. ${ }^{.55}$

Ulasan

Hadis kesebelas ini kedudukannya adalah Muttafaqun ${ }^{\mathrm{c}}$ alaih oleh Imam al-Nawawi di dalam Riyāḍal-Ṣālihīn. ${ }^{56}$ Maka tiada keraguan padanya.

\section{HADIS 12}

Pada hadis Muslim daripada Abi Hurairah bahawasa Rasulullah bersabda :

"Dua adalah jenis tergolong dalam golongan ahli neraka yang saya tidak lihat: orang yang mempunyai seperti ekor lembu dengan mereka dan mereka akan memukul manusia, dan perempuan yang akan berpakaian tetapi telanjang, yang akan cenderung (kepada kejahatan) dan membuat suami mereka cenderung ke arah itu. Kepala mereka akan jadi seperti bonggol unta 'bukhtun' yang condong kepada satu pihak. Mereka tidak akan masuk syurga dan mereka tidak akan cium bau Syurga sedangkan bau Syurga itu boleh dihidu dari jarak ini dan itu., ${ }^{, 57}$ Matan Hadis

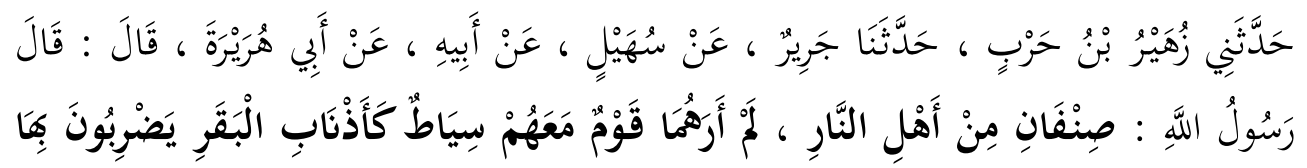

\footnotetext{
${ }^{53}$ Al-Bukhārī, Abū Abd Allah Muhammad bin Ismail, Șaḥị al-Bukhārī, (Qaherah : al-Ṭab ah al-Salafiah : 1400H), h 401 j 4 .

${ }^{54}$ Muslim, Muslim Ibn al-Hajāj Abū al-Hasan al-Qushairi al-Naysābūri, Șaḥị̣ Muslim, (Beyrūt

: Dār Ihyā̄' al-Turāth al-cArabi : 1412H), h 2030 j4.

55 Al-Tirmīdhī, Muhammad bin Isa Ibn Sawrah ibn Mūsā, Sunan al-Tirmīdhī, (Riyạ̣̄ :

Maktabat al-Ma arif : t.th) h 710 .

${ }^{56}$ https:// sunnah.com/riyadussaliheen/1/387

${ }^{57}$ Daud al-Fatani, Kasyf al-Ghummah Fi Ahwal al-Mawta fi al-Barzakh wa al-Qiyamah, (Kuala Lumpur : Khazanah al-Fathaniyah : 2009M), h 220.
} 


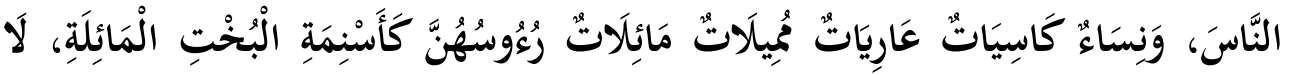

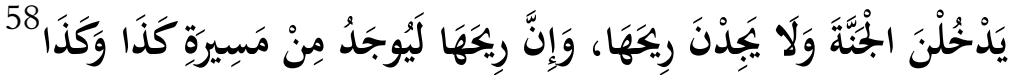

Takhrij : Hadis ini diriwayatkan oleh Imam Muslim.

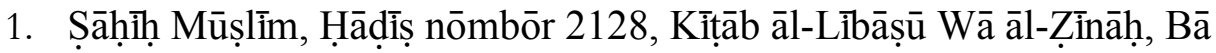

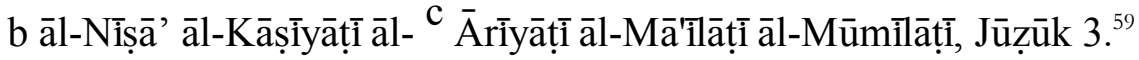

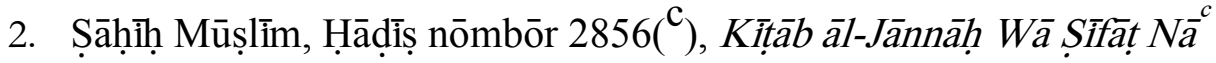
mị̂ā Wā 'Āḥlị̣ā, Bāb āl-Nār Yāụkḥūlūḥā āl-Jābbārūn Wāāl-Jānnāḥ

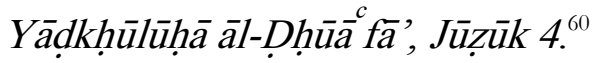

Ulasan

Kedudukan hadis yang kedua belas ini adalah Sahih.

\section{HADIS 14}

Riwayat Syaikhani bahawasa Rasulullah SAW bersabda :

"Orang yang putuskan ikatan kekeluargaan tidak akan masuk syurga." ${ }^{61}$ Matan Hadis

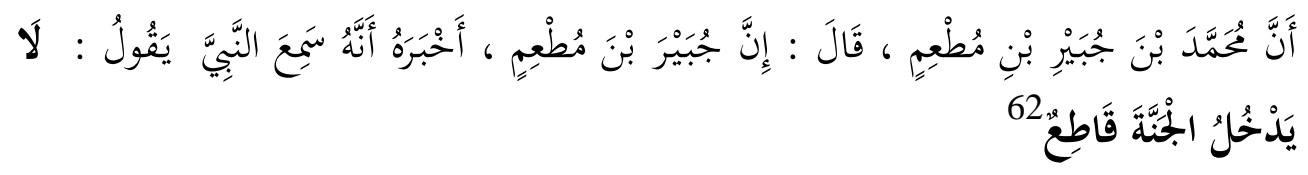

Takhrij : Hadis ini diriwayatkan oleh Imam al-Bukhārī, Muslim, al-Tirmidhī, Abū Dāwud.

\footnotetext{
${ }^{58}$ Muslim, Muslim Ibn al-Hajāj Abū al-Hasan al-Qushairi al-Naysābūri, Ṣaḥị̣ Muslim, (Beyrūt : Dār Ihyā' al-Turāth al-cArabi : 1412H), h 1680 j3.

${ }^{59}$ Muslim, Muslim Ibn al-Hajāj Abū al-Hasan al-Qushairi al-Naysābūri, Șaḥị̣ Muslim, (Beyrūt : Dār Ihyā' al-Turāth al-cArabi : 1412H), h 1680 j3.

${ }^{60}$ Muslim, Muslim Ibn al-Hajāj Abū al-Hasan al-Qushairi al-Naysābūri, Șaḥị̣ Muslim, (Beyrūt : Dār Ihyā̄' al-Turāth al-cArabi : 1412H), h 2192 j4.

${ }^{61}$ Daud al-Fatani, Kasyf al-Ghummah Fi Ahwal al-Mawta fi al-Barzakh wa al-Qiyamah, (Kuala Lumpur : Khazanah al-Fathaniyah : 2009M), h 221.

${ }^{62}$ Al-Bukhārī, Abū Abd Allah Muhammad bin Ismail, Ṣaḥị̣ al-Bukhārī, (Qaherah : al-Ṭab ah al-Salafiah : $1400 \mathrm{H})$, h 89 j 4 .
} 


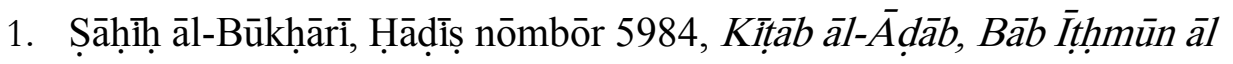
-Qätị , Jūzūk 4 . $^{63}$

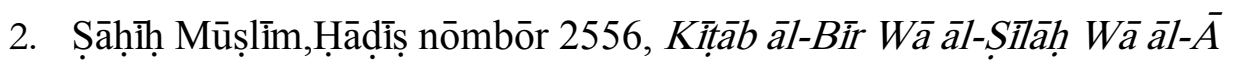

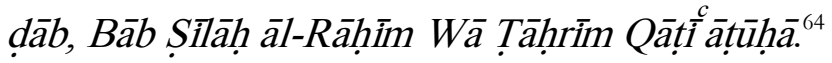

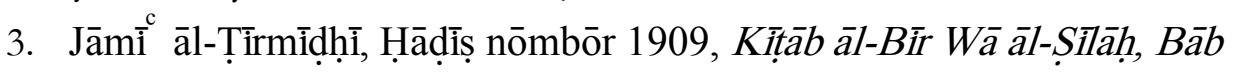
Mā Jāà' Fị̣ilāḥ āl-Rāhịmm. ${ }^{65}$

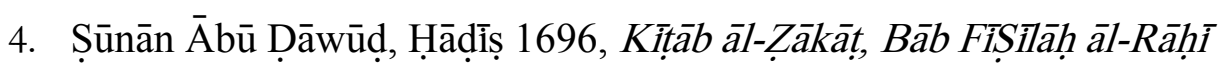
$m^{66}$

Ulasan

Kedudukan Hadis yang keempat belas ini adalah Muttafaqun ${ }^{\mathrm{c}}$ alaih menurut Imam Ibn Ḥajar al-Asqalānī di dalam Bulugh al-Maram. ${ }^{67}$

\section{HADIS 16}

Daripada Abū Hurairāh, katanya aku dengar

'Bahawa Rasulullah SAW bersabda, "Aku telah diperlihatkan pertama (setiap) tiga masuk surga: iaitu kerana syahid, danseseorang yang memelihara dirinya daripada yang haram dan seorang hamba yang disempurnakan ibadah kepada Allah, dan ikhlas kepada tuannyaitu(Allah) ${ }^{68}$

Matan Hadis

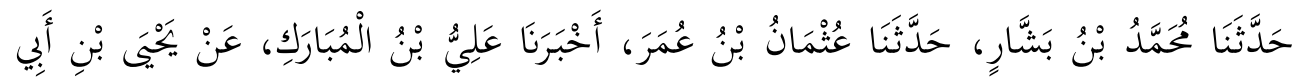

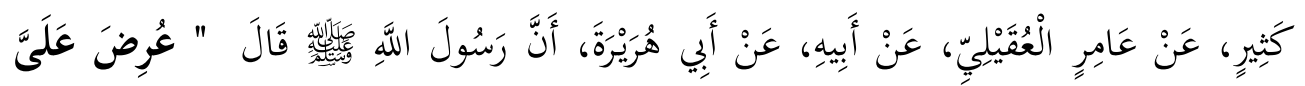

${ }^{63}$ Al-Bukhārī, Abū Abd Allah Muhammad bin Ismail, Șaḥị̣ al-Bukhārīī, (Qaherah : al-Ṭab ${ }^{\square}$ ah al-Salafiah : 1400H), h 89 j 4 .

${ }^{64}$ Muslim, Muslim Ibn al-Hajāj Abū al-Hasan al-Qushairi al-Naysābūri, Ṣaḥị̣ Muslim, (Beyrūt : Dār Ihyā' al-Turāth al-c'Arabi : 1412H), h 1981 j4.

${ }^{65}$ Al-Tirmīdhī, Muhammad bin Isa Ibn Sawrah ibn Mūsā, Sunan al-Tirmīìhī, (Riyāḍ :

Maktabat al-Ma $\square$ arif : t.th) h 437.

${ }^{66}$ Abū Dāwud, Sulaymān Ibn al-Ashcath Ibn Ishāk Ibn Bashir Ibn Shadād Ibn cAmrū al-Azdi al-Sijistāni, Sunan Abū Dāwud, (Riyāḍ : Maktabat al-Ma $\square$ arif : t.th) h 294.

${ }^{67}$ https://sunnah.com/urn/2117640

${ }^{68}$ Daud al-Fatani, Kasyf al-Ghummah Fi Ahwal al-Mawta fi al-Barzakh wa al-Qiyamah, (Kuala Lumpur : Khazanah al-Fathaniyah : 2009M), h 221. 


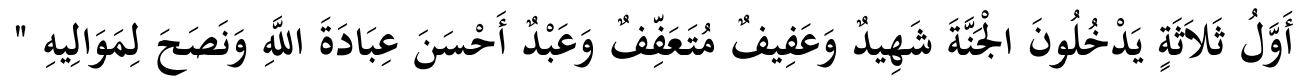

Takhrij : Hadis ini diriwayatkan oleh Imam al-Tirmidhī.

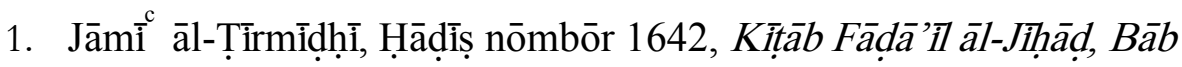

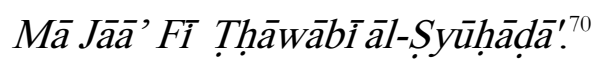

Ulasan

Hadis keenam belas ini kedudukannya adalah Hasan Sahih menurut Imam al-Tirmīdhī dan Sahih menurut Syeikh al-Albani. Maka tiada keraguan pada kedudukannya.

\section{b) Hadis Mardūd}

\section{HADIS 13}

Riwayat 'Abu Dāwud Bahawa:

'Seorang lelaki datang akan nabi maka berkata dia, Ya Rasulullah SAW bahawa bapaku Syeikh besar dan dia ketahui yakni orang yang mengetahui akan pekerjaan qabilah dan orang yang di dalam dosanya dan bahawasanya berita akan dikau bahawa menjadikan 'Urafah itu, kemudian daripadanya kepada aku maka sabda Nabi, bahawa ${ }^{c}$ Urafa itu haq dan tiada bagi manusia daripada 'Urafa dan tetap 'Urafa itu di dalam neraka'.

Matan Hadis

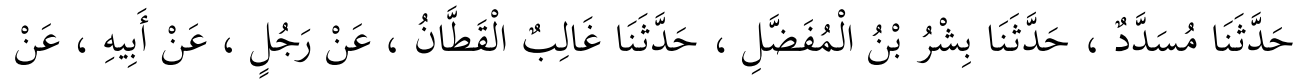

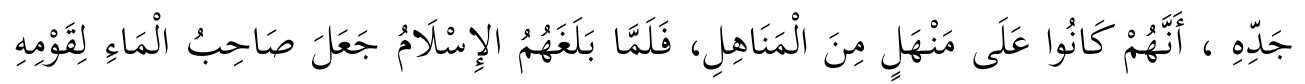

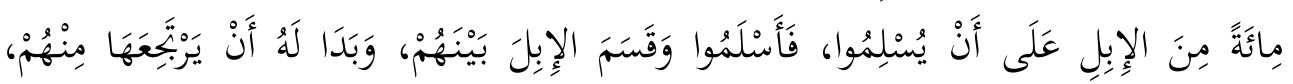

${ }^{69}$ Al-Tirmīidhī, Muhammad bin Isa Ibn Sawrah ibn Mūsā, Sunan al-Tirmīidhī, (Riyāḍ :

Maktabat al-Ma arif : t.th) h 386.

${ }^{70}$ Al-Tirmīidhī, Muhammad bin Isa Ibn Sawrah ibn Mūsā, Sunan al-Tirmīdhī, (Riyāḍ :

Maktabat al-Ma arif : t.th) h 386. 


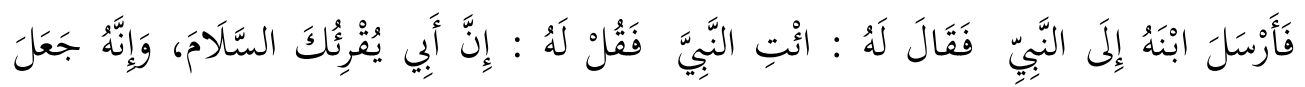

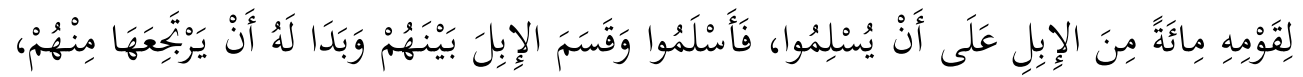

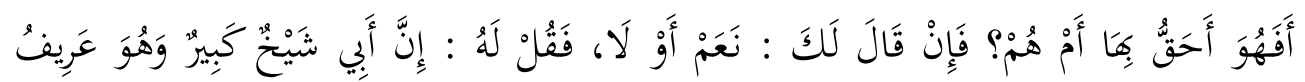

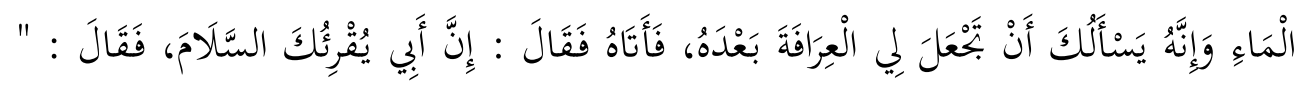

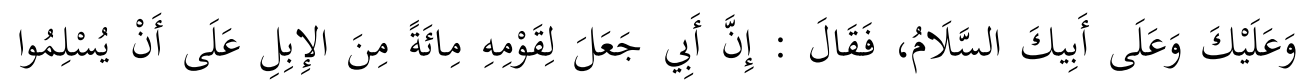

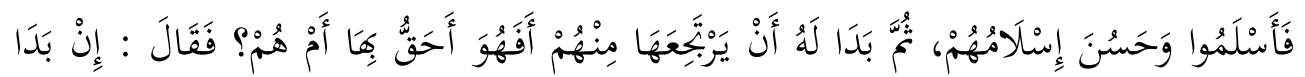

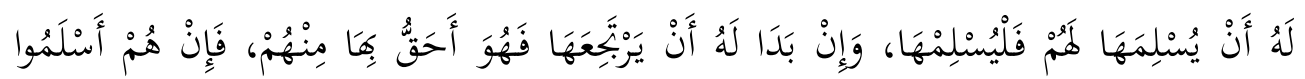

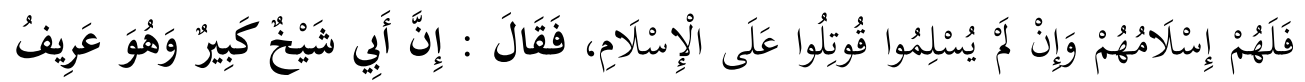

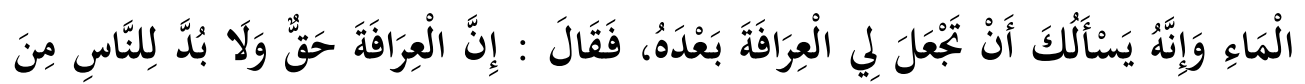

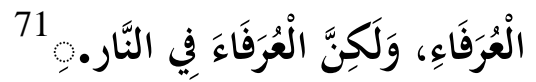
Takrij : Hadis ini diriwayatkan oleh 'Abu Dāwud.

1. Șūnān ‘Ābū Ḍāwūụ, Hậ̣ịị nōmbōr 2934, Kịtāb āl-Khārāj Wāāl-İmā rāḥ Wā āl-Fāīi, Bāb Fĩ āl- ${ }^{c} \bar{A}$ rāfāḥ. ${ }^{72}$

Ulasan

Kedudukan hadis keenam belas ini didiamkan oleh Imam Abu Dawud yang mana bermakna Soleh ${ }^{73}$ manakala dihukumkan $\mathrm{Da}^{\mathrm{c}}$ if menurut Syeikh alAlbani.

\section{HADIS 15}

Riwayat Abu Dawud bahawasa Rasulullah SAW bersabda :

"Orang yang secara salah mengambil cukai tambahan (sahib maks) tidak akan masuk syurga." ${ }^{74}$

\footnotetext{
${ }^{71}$ Abū Dāwud, Sulaymān Ibn al-Ashcath Ibn Ishāk Ibn Bashir Ibn Shadād Ibn cAmrū al-Azdi al-Sijistāni, Sunan Abū Dāwud, (Riyāḍ : Maktabat al-Ma ${ }^{\square}$ arif : t.th) h 523.

${ }^{72}$ Abū Dāwud, Sulaymān Ibn al-Ashcath Ibn Ishāk Ibn Bashir Ibn Shadād Ibn cAmrū al-Azdi al-Sijistāni, Sunan Abū Dāwud, (Riyāḍ : Maktabat al-Ma ${ }^{\square}$ arif : t.th) h 523.

73 ansarul-hadis.blogspot.my/2011/04/setiap-hadith-hadith-yang-didiamkan.html
} 
Matan Hadis :

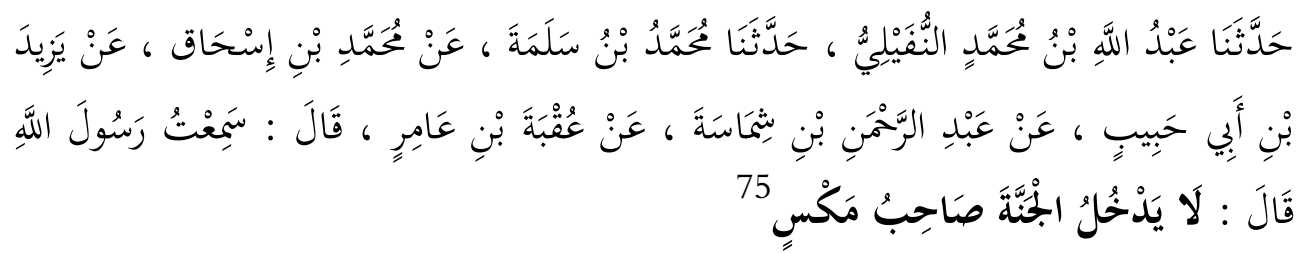

Takhrij : Hadis ini telah diriwayatkan oleh Imam Abū Dāwud.

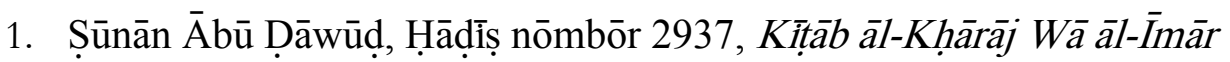

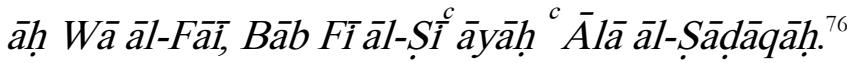

Ulasan

Kedudukan hadis keenam belas ini didiamkan oleh Imam Abu Dawud yang mana bermakna Soleh ${ }^{77}$ manakala dihukumkan $\mathrm{Da}^{\mathrm{c}}$ if menurut Syeikh alAlbani.

\section{c) Hadis yang Tidak Dijumpai}

\section{HADIS 8}

Dan Hadis pula

'Ahli neraka itu tiap-tiap bakhil yang banyak dusta'.

Matan Hadis

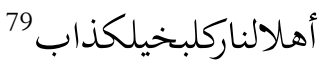

Takhrij : Tidak dijumpai

Ulasan

Setelah dilakukan kajian secara mendalam dan matan hadis dari beberapa kitab hadis sama ada sumber asal ataupun serupa asal, kitab-kitab

\footnotetext{
${ }^{74}$ Daud al-Fatani, Kasyf al-Ghummah Fi Ahwal al-Mawta fi al-Barzakh wa al-Qiyamah, (Kuala Lumpur : Khazanah al-Fathaniyah : 2009M), h 221.

${ }^{75}$ Abū Dāwud, Sulaymān Ibn al-Ashcath Ibn Ishāk Ibn Bashir Ibn Shadād Ibn cAmrū al-Azdi al-Sijistāni, Sunan Abū Dāwud, (Riyāḍ : Maktabat al-Ma ${ }^{\square}$ arif : t.th) h 523.

${ }^{76}$ Abū Dāwud, Sulaymān Ibn al-Ashcath Ibn Ishāk Ibn Bashir Ibn Shadād Ibn cAmrū al-Azdi al-Sijistāni, Sunan Abū Dāwud, (Riyāẹ : Maktabat al-Ma ${ }^{\square}$ arif : t.th) h 523.

77 ansarul-hadis.blogspot.my/2011/04/setiap-hadith-hadith-yang-didiamkan.html

${ }^{78}$ Daud al-Fatani, Kasyf al-Ghummah Fi Ahwal al-Mawta fi al-Barzakh wa al-Qiyamah, (Kuala Lumpur : Khazanah al-Fathaniyah : 2009M), h 218.

${ }^{79}$ Abdul Wahab, Mukhtasar Tadhkirah al-Qurtubi, (Istanbul : Dar al-Syafqah : 2000), h 178.
} 
takhrij ataupun dengan takbrij melalui perisian komputer seperti jawami al-kalim, maktabah shamela, laman web dorar.net, islam web.com dan lain-lagi, setakat ini masih belum ditemukan nasnya.

\section{HADIS 9}

Dan pada hadis lain pula,

'Ahli neraka itu tiap-tiap orang yang jahat perkataannya lagi khianat'.

Matan Hadis

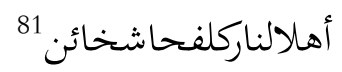

Takhrij : Tidak dijumpai

Ulasan

Setelah dilakukan kajian secara mendalam dan matan hadis dari beberapa kitab hadis sama ada sumber asal ataupun serupa asal, kitab-kitab takbrij ataupun dengan takhrij melalui perisian komputer seperti jawami al-kalim, maktabah shamela, laman web dorar.net, islam web.com dan lain-lagi, setakat ini masih belum ditemukan nasnya.

\section{HADIS 10}

\section{Dan pada satu riwayat}

'Ahli neraka itu ḍa î îf akalnya dan tiada hirau akan agama'. ${ }^{82}$

Matan Hadis

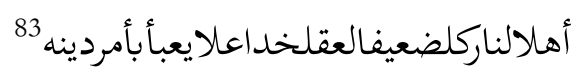

Takhrij : Tidak dijumpai

Ulasan

Setelah dilakukan kajian secara mendalam dan matan hadis dari beberapa kitab hadis sama ada sumber asal ataupun serupa asal, kitab-kitab

\footnotetext{
${ }^{80}$ Daud al-Fatani, Kasyf al-Ghummah Fi Ahwal al-Mawta fi al-Barzakh wa al-Qiyamah, (Kuala Lumpur : Khazanah al-Fathaniyah : 2009M), h 218.

${ }^{81}$ Abdul Wahab, Mukhtasar Tadhkirah al-Qurtubi, (Istanbul : Dar al-Syafqah : 2000), h 178.

${ }^{82}$ Daud al-Fatani, Kasyf al-Ghummah Fi Ahwal al-Mawta fi al-Barzakh wa al-Qiyamah, (Kuala Lumpur : Khazanah al-Fathaniyah : 2009M), h 218.

83 Abdul Wahab, Mukhtasar Tadhkirah al-Qurtubi, (Istanbul : Dar al-Syafqah : 2000), h 178.
} 
takbrij ataupun dengan takbrij melalui perisian komputer seperti jawamt alkalim, maktabah shamela, laman web dorar.net, islam web.com dan lain-lagi, setakat ini masih belum ditemukan nasnya.

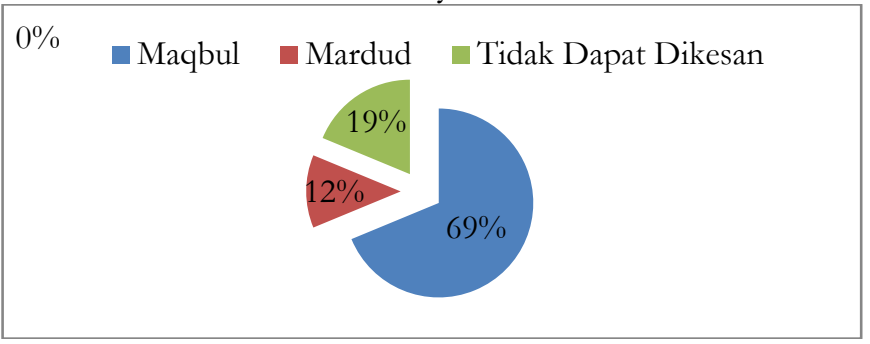

\section{Simpulan}

Rajah 1.0 Peratusan mengikut pembahagian kedudukan hadis

Kajian kedudukan terhadap hadis-hadis yang dikemukakan di dalam penulisan ini telah menghimpunkan sebanyak 16 hadis dalam Bab 16 iaitu tentang Syurga dikelilingi dengan perkara yang tidak disukai manakala neraka dikelilingi dengan keinginan, serta sifat ahlinya yang kesemua itu, telah dikaji kedudukannya.

Hasil kajian terhadap 16 hadis yang dijalankan mendapati 3 hadis kedudukannya Muttafaqun alaih, 7 berkedudukan Șaḥị̣, 1 berkedudukan Hasan, 2 hadis $\mathrm{Da}^{\mathrm{c}}$ if, 3 hadis yang tidak dapat dikesan sumber asalnya. Diantara 13 hadis yang ditemui sumbernya, 11 hadis maqbūl dan 2 adalah mardūd.

Pihak penulis ingin mencadangkan kepada penulis-penulis ilmu Islam supaya lebih teliti dan cermat di dalam tulisannya supaya merujuk hanya kepada hadis yang berkualiti di dalam penulisan mereka serta dinyatakan sumbernya.Sekiranya terdapat hadis yang mardud di dalam penulisan, hendaklah dijelaskan dengan keterangan agar pembaca lebih cermat dan berhati-hati terhadap kenyataan yang dikemukakan itu.

Berhubung dengan kajian ini, penulis amat berharap supaya dapatan kajian dapat melengkapkan kedudukan hadis di dalam Kitab ini yang mana menjadi rujukan pondok-pondok dan disamping menjaga khazanah Nusantara ini

\section{Daftar Pustaka}

Abdul Wahab al-Sya'rani. 2000.Mukhtasar Tadhkirah al-Qurtubi. Istanbul : Dar al-Syafqah. 
Abdullah al-Qari. 1967.Pujangga Syeikh Daud al-Fatani. Majalah Dian.

Abū Dāwud, Sulaymān Ibn al-Ash'ath Ibn Ishāk Ibn Bashir Ibn Shadād Ibn 'Amrū al-Azdi al-Sijistāni. t.th.Sunan Abū Däwud. Riyāḍ : Maktabat al$\mathrm{Ma}$ arif.

Al-Bukhārī, Abū'Abd Allah Muhammad bin Ismail. 1400.Sahị̣ alBukbāāi.Qaherah : al-Tab ${ }^{\mathrm{c}}$ ah al-Salafiah.

Al-Nasā'i, Abu ${ }^{c}$ Abd al-Rahman Ahmad Ibn Shu ayb. T.th.Sunan al-Nasā̄i. Riyāọ : Maktabat al-Ma arif .

Al-Tirmīdhī, Muhammad bin Isa Ibn Sawrah ibn Mūsā. t.th.Sunan al-Tirmī dhĩ. Riyāọ : Maktabat al-Ma arif .

ansarul-hadis.blogspot.my/2011/04/setiap-hadith-hadith-yang-didiamkan.html Daud al-Fatani. 2009. Kasyf al-Ghummah Fi Abwal al-Mawta fi al-Barzakh wa alQiyamah. Kuala Lumpur : Khazanah al-Fathaniyah.

Fauzi Deraman. 1997. Kedudukan Hadis Dalam Kitab Jawi : Karya-karya Syakh Dand B Abdullah al-Fatani. Tesis Doktor Falsafah, Akademi Pengajian Islam: Universiti Malaya.

https://sunnah.com/riyadussaliheen/1/101 https://sunnah.com/riyadussaliheen/1/387 https://sunnah.com/urn/2117640

Ismail Che Daud. 2001.Tokoh-tokob Ulama Semenanjung Melayu (1). Kota Bharu : Majlis Ugama Islam dan Adat Istiadat Melayu Kelantan. 